\title{
Article \\ Dhaka Sitting on a Plastic Bomb: Issues and Concerns around Waste Governance, Water Quality, and Public Health
}

\author{
Md Nadiruzzaman ${ }^{1, *(D)}$, Hosna Jahan Shewly ${ }^{2}\left(\mathbb{D}\right.$ and Afsana Afrin Esha ${ }^{3}$ (D) \\ 1 Research Group Climate Change and Security (CLISEC), Institute of Geography, Center for Earth System, \\ Research and Sustainability (CEN), University of Hamburg, 20144 Hamburg, Germany \\ 2 Department of Social and Cultural Sciences, Fulda University of Applied Sciences, 36037 Fulda, Germany; \\ hosna.shewly@sk.hs-fulda.de \\ 3 International Centre for Climate Change and Development (ICCCAD), Dhaka 1229, Bangladesh; \\ 012esha@gmail.com \\ * Correspondence: md.nadiruzzaman@uni-hamburg.de
}

Citation: Nadiruzzaman, M.; Shewly, H.J.; Esha, A.A. Dhaka Sitting on a Plastic Bomb: Issues and Concerns around Waste Governance, Water Quality, and Public Health. Earth 2022, 3, 18-30. https://doi.org/ 10.3390/earth3010002

Academic Editors: Laura Bulgariu and Charles Jones

Received: 17 November 2021

Accepted: 4 January 2022

Published: 6 January 2022

Publisher's Note: MDPI stays neutral with regard to jurisdictional claims in published maps and institutional affiliations.

Copyright: (C) 2022 by the authors. Licensee MDPI, Basel, Switzerland. This article is an open access article distributed under the terms and conditions of the Creative Commons Attribution (CC BY) license (https:// creativecommons.org/licenses/by/ $4.0 /)$.

\begin{abstract}
Plastic, an offer of modernity, has become one of the essential parts of our everyday life. However, it is presenting a massive threat in altered forms, to our health and environment. Plastic does not only pollute the surface environment, freshwater, and marine ecosystems, but toxic elements released from plastics also percolate down the surface and contaminate groundwater, which we often use as 'safe' drinking water. This probable future risk is deeply rooted in the entire governance infrastructure of plastic waste which could potentially lead to contamination of groundwater. Thus, a state-sponsored 'safe drinking water' initiative could contrarily produce a 'risk society'. A recent study finds $81 \%$ of tap water samples collected worldwide contained plastic pollutants, which means that annually we may be ingesting between 3000 and 4000 microparticles of plastic from tap water. Based on review, ethnographic observations and interviews, and lived experience in a plastic-wrapped city (Dhaka), this paper sheds light on the complex interface of plastic, water, and public health, on the relevance of Beck's 'risk society' to understand this complexity, and on replicating the idea of 'risk society' in the case of Bangladesh. Through understanding the plasticgroundwater-waste management nexus, this paper highlights and advocates for a new strategy of plastic governance in modern states.
\end{abstract}

Keywords: Dhaka; plastic; waste governance; drinking water; public health; risk society

\section{Introduction}

In the early twentieth century, the invention of Bakelite, the world's first synthetic plastic, laid the foundation of the Polymer Age. Over the last century, plastic has flourished as one of the most significant and essential parts of our everyday life. Humans had benefited from polymers since roughly about $1600 \mathrm{BC}$ when the ancient Mesoamericans first manufactured natural rubber into balls, figurines, and bands [1]. Moving forwards, men had relied progressively on plastics and rubber. Experiments first began with horns, natural polymers, natural rubber, resins, and waxes, until the nineteenth century, when modern thermoplastics were developed. Since its rise in the 1950s, because of its affordability, durability, malleability, lightweight compared to other trending items and due to a lack of environmental awareness and appropriate policy considerations, global plastic production had grown to 322 million tonnes in 2015. Plastic set up the conditions for consumerism and international trade and, while the existing systems themselves became progressively reliant upon the diverse forms of plastic [2]. Soon enough, plastic became the footing of advanced capitalism. Due to its complying property to withstand the effects of the environment, adjustable characteristics, and being untouched by time itself, plastic soon became the fuel for development. 
The first plastic industry in Bangladesh started its journey as a small-scale industry in the 1960s by making plastic toys, photo frames, and plastic spare parts for the jute mills. The industry experienced robust growth with injection and film grade machines in the 1980s [3]. Over the last 30 years, the plastics industry has witnessed speedy growth due to the introduction of a free-market economy. Over the last 20 years, the polymers import increased from around 14,000 metric tons in 1990 to 696,500 metric tons in 2011 [3]. Bangladesh is employing about two million people in approximately 3000 plastic product manufacturing units. The major products are readymade garments (RMG), construction material, packaging, and household goods exported to different countries. As a result, plastics brought in more earnings, fuelling the journey towards a modern society. This large and growing domestic and export-oriented market spread out promptly, contributing to around $1 \%$ of the national GDP with a total earning of USD 337 million exports. Although the prompt expansion of plastics brought promises of modernity, with the emergence of large-scale plastic production, Bangladesh has now encountered difficulties handling the vast amount of plastic waste similar to other nations around the world. The durability and increasing usage of plastics, which were beneficial at the beginning, now is creating a major waste management problem. In response, the state has not done much for raising public awareness and enforcing environmental protection and corporate responsibilities against plastic pollution.

Approximately half of the global plastic waste is from disposable single-use packaging, agricultural films, and disposable consumer items, $25 \%$ from durable infrastructures such as cable coverings, pipes, and structural materials, and the rest are from consumer applications with a median lifespan, such as in electronic goods, furniture, and vehicles [4]. Since the 1940 s, we have produced about 6.3 billion tonnes of plastic waste and buried approximately $79 \%$ of them in landfill sites or directly into the natural environment. Over time, plastic accumulation is influencing any environment it reaches while remaining unstirred itself. The characteristics that have led plastic to be alluring are now causing provocations in the promises of modernity. The benefits seemed more profitable than the shadowed consequences. But now, plastic has been posing a massive risk to the environment and marine life. Human health is also at the stake of plastics' adverse impact. Plastic pollutes the terrestrial and aquatic environment by remaining in its original chemical form for a much longer period as Microplastics. Slowly degrading plastic materials release toxic chemicals into the surrounding environment and pollute its soil and water. Plastic pollutants could also percolate down the surface and contaminate groundwater, which we often use as 'safe' drinking water. This particular issue becomes problematic when we look into the entire governance of plastic waste management, pollution at plastic - groundwater interface, and how a state-sponsored 'safe drinking water' campaign could contrarily produce a 'risk society' in the global South and beyond.

A recent study analyses 159 tap water samples from fourteen countries and finds $81 \%$ of tap water samples contained plastic pollutants. Depending on the volume of pollutants in the water and peoples' drinking habit, the research predicts that people may be ingesting between 3000 and 4000 microparticles of plastic from tap water per year [5]. The plastic pollution problem appears to be more critical in coastal cities of developing nations, through where high volumes of plastics enter the ocean [6]. Interestingly, $90 \%$ of the top 20 global plastic generators are from developing countries [7]. Again, marine pollution is a huge problem leading to an array of abnormal changes to the water ecosystem and affecting human health over time, which has drawn significant attention to media and academic outlets. However, plastic pollution to drinking water could be detrimental to human health over time, though this research is still sparse within the scientific group [8]. Such risks steadily cross man-drawn administrative boundaries, and gradually amplify its threat to wider civilization.

In the above discussion, we elaborated on how plastic evolved in the chemistry lab and gradually slipped in and flourished as a necessary item of our everyday lives. It was in the early 1970s scientists started giving caution signals about plastic pollution $[9,10]$. 
In half a century from the first warning, plastic became an imminent threat to the future environment and public health. Borrowing the idea of Beck's 'risk society' [11], this article strives to understand this complex interface of plastic waste governance, drinking water contamination, and future public health risk in the case of Bangladesh. Thus, the particular focuses are on-(i) impending dangers to public health from plastic toxicities to drinking water; (ii) the problems in the governance of plastic wastes as these complexities play a major role in determining the degrees of impact. The study focuses on Dhaka city, where lenient laws and massive plastic production imposes great risks to a population of 20 million. This paper also advocates for innovation and new strategies of plastic governance at the state level. Strategies such as in-depth research, material reduction, the mechanism for end-of-life recyclability, improving recycling and treatment technology, procedures to reduce consumption, and applying green chemistry life-cycle analyses implemented through the blended actions of the public, industry, scientists, and policymakers, will bring progressing results.

In the following section, we explained how we gathered data and evidence to develop the paper. Based on fieldwork observations and analysis, we gradually shifted our focus to show the flow of plastic waste from dumping to open environment in Bangladesh, future health risks, scopes of efficient management in the existing policy framework, and what we could do about it.

\section{Methods}

Ulrich Beck used the example of the Cheronyble nuclear power plant to critically reflect on modernity and governmental responsibilities to ensure public safety from future risks [11]. Following a similar theoretical focus, this paper will explore how plastics are flowing from their end-users to a landfill station by changing numerous hands and places. Thus, the paper will look into the governance of plastic waste management and its relevant policies and guidelines in Bangladesh.

Understanding the journey of plastic from its producers to different bearers in its lifespan is conceptualized through ethnographic observations. Between 2017 and 2018, we made a list of single-use plastic waste produced at our home, observed items in grocery shops and their packaging, randomly checked waste dumping points to validate and update our list. From our everyday fresh vegetables and food to toiletries, and other essential goods, all are wrapped and packaged in plastic. We randomly approached ten people from our close network to learn-(a) how many items they bought in the last three days and how many of them are plastic covered, and (b) How they manage their plastic waste. This approach employs many observations to document its flow and use, in-depth discussions with other users to note what they do with plastic once it has been used and whether they understand its environmental consequences. We followed the waste, how it is collected, where it is disposed of, who collects them, the network of waste management agents, etc. We interviewed six local level waste collectors, who go door to door every day to collect kitchen waste. Since they are recruited by the local neighborhood committees on a very informal arrangement, talking to them at a local tea stall over a cup of tea gave us detailed information on how they categorize the different quality of wastes, particularly plastic, and what are the life cycles of those waste. We have also spoken to the city corporation who is responsible for all waste management within the city. We learned about the flow of waste from designated dumping stations to the landfilling sites, waste segregation and management, relevant policies and bottlenecks, and the way forward. We maintained a research ethical code of conduct. All the informants were briefed about the research and data protection at the very beginning. We decided not to disclose any of our research informants' identities. We asked their permission before tape recording our conversation and access to these data was restricted only to the authors.

Simultaneously, we reviewed existing policies, legislation, guidelines on plastic production, use, and management. Since the major focus of this paper is to understand how plastic toxicity would affect our future health through contaminating groundwater, the 
authors searched to find relevant research to make a background case. As revealed from the search results, most of the papers focus on how plastics harm the marine environment and focus on the food chain, food security, pollution management, metal contamination, and overall environmental impacts. Few studies have also talked about the effects of toxic plastic particles in the air and human health.

\section{Results and Discussions}

\subsection{Beck's Risk Society: Plastic and Public Health}

As Beck (1992) argues, we are facing the unwanted and obscured consequences of modernity, where industries both create and manifest legitimate risks that often go out of their hands [11]. Moreover, regrettably, these industries are beginning to profit from their secondary problems, ignoring their role in origin. Beck's theory illuminates such piercing issues in the proliferation of hazardous technology, the liabilities of economic growth, and the insufficiency of reductionist scientific research [12]. Modern society is constructed around and impacted by new, never existing qualities of risks that could not be analyzed beforehand. Society lives in the future and is now manifested by the risks produced by modernity itself. This is more like a manufactured risk where high levels of human agency are constantly being involved in inducing and mitigating such risks. In Beck's risk society, risks are universal and permanent. Since everyone in society is arguably equally exposed to these manufactured risks, and since the consequences are presented and suffered in the future, we cannot call back the mistakes already made in the past and undo the chain of events. Modern risks threaten individuals, landscapes, and human society in new and unique ways [13]. These disturbances are unlike all the floods, earthquakes, and other natural catastrophes that have continued to strike humankind but are now imperceptible by direct human sensory perceptions, capable of transcending generations. The increasing complexity of such risks also exceeds the capacity of topical mechanisms for compensating the victims. Though the concept of a 'risk society' is more appropriate and relevant to a technologically modern world, when we take the plastic industry as an artifact of modernity, the nature of threats it imposes to public health and the total environment, it fits very well under the discussion of 'risk society' across the globe.

Considerable quantities of plastic have accumulated in the water cycle and environment through processes both known and unknown to us. As a result, toxicity is growing in nature, and the threat imposed is on individuals to populations. Microplastics can serve as vectors of transport carrying toxic chemicals in the ecosystems. On the other hand, they are themselves a cocktail of hazardous substances which are often added voluntarily during their production as additives to improve desirable qualities such as increasing polymer properties and prolonging their life [14]. As plastics degrade through processes such as hydrolytic degradation, photodegradation, thermo oxidative degradation, and biodegradation by microorganisms [15], it releases a range of reinforcing fillers, plasticizers, antioxidants, UV stabilizers, lubricants, dyes, and flame-retardants [16] impacting all living organisms at a sub-cellular level. The impacts of the most common plastic polymers with known health effects are listed in Table 1.

Plastic waste management and the impact of plastic on the global environment is one of the major concerns at present. Substantial quantities have infiltrated the natural environment and landfills undetected and uncared for. Plastic is a double-edged sword, both leaching out and attracting toxic chemicals. It may contain many harmful substances and hazardous substances, which could potentially cause countless health issues such as dizziness, eye irritation with impaired vision, respiratory problems, liver dysfunction, cancer, skin diseases, headache, birth effect, reproductive health problem, cardiovascular, genotoxic, and gastrointestinal issues. These are the consequences of incautious and irresponsible commercialization of plastic, which led to $50 \%$ single-use plastic applications worldwide, insufficient post-use treatment, poor recyclability and reusability rates, and a high risk of disintegration into microplastics. As a result, economic development and 
environmental degradation expedition continue fluidly, with plastics having a prominent role in navigation.

Table 1. Impact of plastic polymers and monomers on human health.

\begin{tabular}{|c|c|c|c|}
\hline $\begin{array}{l}\text { Type of Polymers } \\
\text { and Monomers }\end{array}$ & Sources & Health Effects & References \\
\hline Polyethene & $\begin{array}{l}\text { Garbage bags; coated papers, Milk and } \\
\text { detergent bottles: boil-in-bag pouches }\end{array}$ & Increased cytotoxicity at the cell level & [17] \\
\hline Polyvinyl Chloride (PVC) & $\begin{array}{l}\text { Construction pipe; meat wrap: cooking } \\
\text { oil bottles }\end{array}$ & Carcinogenic and corrosion (acidic) & [18] \\
\hline Polystyrene (PS) & $\begin{array}{l}\text { Disposable foam dishes and cups; } \\
\text { cassette tape cases }\end{array}$ & $\begin{array}{l}\text { Affect human bronchial epithelial } \\
\text { cells.Decrease in subsequent } \\
\text { iron absorption }\end{array}$ & [19-21] \\
\hline $\begin{array}{c}\text { Polyethylene } \\
\text { Terephthalate (PET) }\end{array}$ & $\begin{array}{l}\text { Soft drink bottles; food and } \\
\text { medicine containers }\end{array}$ & $\begin{array}{l}\text { Formation of reactive oxygen species } \\
\text { (ROS); neurological (e.g., hearing and } \\
\text { visual impairment); cardiovascular } \\
\text { and endocrine deficits }\end{array}$ & [22] \\
\hline Polypropylene (PP) & $\begin{array}{l}\text { Syrup bottles; yogurt tubs: } \\
\text { office furniture }\end{array}$ & Hypersensitive Immune Response & [23] \\
\hline Phthalates & $\begin{array}{l}\text { Credit cards, flooring and wall } \\
\text { coverings, food containers, medical } \\
\text { implants, and window frames }\end{array}$ & $\begin{array}{l}\text { Risks in pubertal development, } \\
\text { reproductive health, allergies, rhinitis, } \\
\text { asthmatic reactions, and } \\
\text { direct toxicity. }\end{array}$ & {$[24,25]$} \\
\hline
\end{tabular}

Cracked limestone aquifers, which supply $25 \%$ of global drinking water, are expected to be among the earliest aquifers to become contaminated with microplastics. This is because they are highly porous and receive surface water runoff, outputs from waste treatment work, etc. Panno et al., (2019) studied karst groundwater aquifers which are open systems and are prone to contamination by surface-borne pollutants, especially tiny ones which can easily pass through. In his study, microplastics such as fibers were found from septic effluent and anthropogenic liter [26]. They studied groundwater samples and counted samples with specific morphologies (bead, fiber, fragment, foam, and film) and recorded color. The chemical composition of the microplastics was obtained by pyrolysis GCMS. The bio-concentration of such contamination can cause ecosystem disturbances and has caught the attention of researchers worldwide.

Because most plastics found in the ocean originate from land, studies targeting marine and freshwater ecosystems, especially surface water has increased over the years [27]. The surfaces of plastics act as adsorption sites for environmental pollutants and other toxins and support the growth of bacteria. As the surface area to volume ratio increases, the plastics can bio-accumulate into systems and release more of their constituent chemicals, increasing toxicity in food chains, affecting microbial communities and organisms. Thorough research on the mechanisms of occurrence, fate, and transportation of degraded plastics in groundwater is yet to be concluded.

\subsection{Plastic Waste Management in Bangladesh: A Case of Dhaka City}

Despite being the first country to ban the use of poly shopping bags since 2001, Bangladesh is ranked 10th on the list, where extensive use of single-use plastics, mismanagement of these in areas, accompanied by improperly managed landfills lacking waste separation procedures due to lenient laws are widespread [28]. High population densities all over the country, especially in the capital city Dhaka, exaggerate the condition. The amount of waste generated is affected by the average income of the people, and as income rises in the megacity, waste production and inappropriate disposal are increasing exponentially. As plastics degrade over time, this massive amount of plastics in landfills is imposing a threat to the environment visibly and undetectably through routes such as soil and groundwater. Such consequences are alarming in a megacity where $84 \%$ of 
the municipal water is supplied from groundwater resources. The impact will be felt most by the poorest of the poor. They are at a higher risk for exposure to health hazards and environmental degradation resulting in severe and long-lasting negative impacts on livelihood security, economic development, and cultural ways of life [29].

Bangladesh continues to grow in the global plastic market, as plastics industries produce essential products such as garments accessories, construction material, packaging, and household items. Our everyday toiletries, such as toothpaste, shampoo, bath soap, body cream, and almost all items, are available in plastic wrap in different sizes from as tiny as a single-use. Street food and tea stalls have replaced porcelain plates and cups with single-use plastic items. Thus our affordability and demand for consumer products are neoliberalized by the unregulated use of polymer wraps. Drinking water, beverages, snacks, food items, and most of the daily food items come in some sort of plastic case or container. Most of these plastic items have no use right after consuming the product inside them. As an aggregate, Bangladesh generates 336,000 tons of plastic waste per year, which is only projected to rise over time.

Despite its potential environmental cost, the plastic industry is booming in Bangladesh. In the fiscal year 2017-2018, Bangladesh exported around USD 1 billion worth of plastic products, which makes plastic the 12th highest export earning sector in the country [30]. Currently, more than 2 million people are employed in plastic industries in Bangladesh and the domestic market size is reported to be at USD 1.9 billion with 20 percent year on year growth [28]. The flourishing plastic economy synchronized with the country's plastic consumptions too. The average annual per capita plastic consumption is about $6 \mathrm{~kg}$ in Bangladesh [30]. BIGD ran a detailed waste audit among more than 600 households across different socio-economic neighborhoods in Dhaka City. As BIGD calculates, per capita average waste generation is $377 \mathrm{gm}$ per day out of which $366 \mathrm{gm}$ is organic and the rest $11 \mathrm{gm}$ is inorganic [31]. Plastic items contain 60 percent of all household inorganic wastes. With the rise of population and expansion of the plastic industry, plastic waste rises 3.5 folds from 178 tons per day in 2005 to 646 tons per day in 2020 [28].

Most plastic waste is neither collected properly nor disposed of appropriately to avoid harmful impacts on the environment and public health. For example, while traveling from the capital city (Dhaka) to a southern district (Barisal) by ship, we observed that at the end of the journey all the public spaces of the ship were cleaned and the waste bins were cleared into the river. We also observed a similar scenario in cases of waste management at the household level. Despite having options of availing community-based waste collection services, many households in the city clean their private space and dump their waste into adjacent drainage and swedge system or in a public space. The flattened space in Figure 1 is a natural canal filled up with household wastes. The adjacent slum area always gets flooded even with light rain showers. Neither at the household nor institutional level, there is a huge deficiency of awareness to distinguish between organic and inorganic waste. In our interviews with both the north and the south city corporations officers of Dhaka, we came to know that the city corporation authorities have never taken any initiative to separate plastic from organic wastes at any level of waste collection.

Due to a different cultural orientation around waste management inherited from less dense rural natural settings, which does not suit a tight urban space, the structural urban waste management system was absent in the late 1970s and the early 1980s. City-dwellers never had any orientation to the cultural practice of structured waste management. A combination of inefficient policy, fragile infrastructure, weak enforcement, lack of priority, and poor political leadership constrained Bangladesh's environmentally sustainable waste management system. Neither the producer, the consumer, nor the local council feels obliged to take those plastics out of nature. Plastics keep degrading and flowing in nature for centuries. As a result, significant amounts of single-use plastics fail to travel to landfills through informal and formal waste collection systems in the major cities. Instead, they are disposed of discretely and often clog up our drainage and sewage system. Big cities 
like Dhaka and Chittagong experience localized floods following any heavy pouring, and plastic is often one of the major reasons.

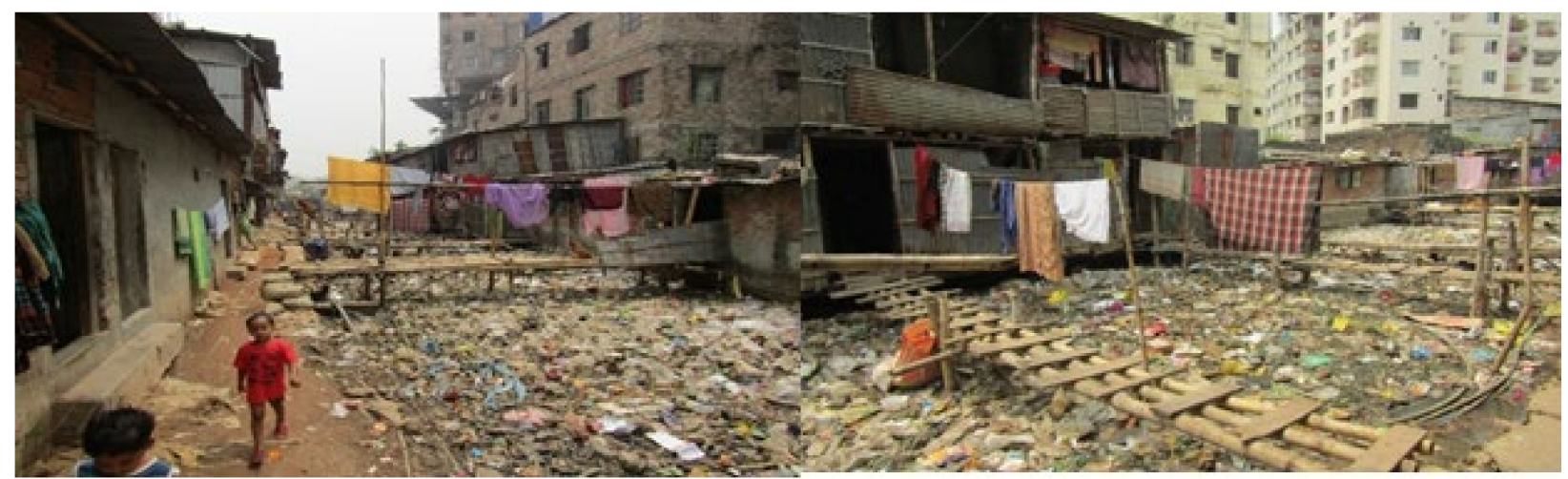

Figure 1. Mosaic of single-use plastic creating thick layers in an urban slum in Dhaka city (Source: Author).

We certainly are unable to see with our bare eyes how plastics are intoxicating our surroundings. However, its unmanaged and vivid presence as waste in our surrounding environment is hard to miss. Encountering polluted landscapes around us, bags fluttering in the wind, tangled wires covered in plastic, ocean pollution, clogged drains, heaps of plastic piled in dumps, and in the corners of streets are familiar scenarios in Bangladesh and other countries. Nevertheless, these untold stories of plastic do not end within our sight. They continue to borrow life from other organisms, not excluding humans, through routes we consider safe, one of which is groundwater.

Plastic waste is grossly classified under two categories-hard and soft. Plastic bottles and cases fall under hard plastics manually collected from domestic, local, and regional dumping stations by waste collectors, primarily women, and children. In Figure 2, we see two hanging sacks on the door of the purple van, where the waste collectors manually separate plastic, paper, and other saleable items as they collect waste door to door. They leave only the single-use plastic at the dumping point as they incur no value to them. Thus, hard plastics travel from waste collectors through local vendors, wholesales, and other hands to the recycling factories. and are eventually exported as flakes and recycled for alternative uses. Soft plastics are mainly single-use plastics, often thrown away discretely or disposed of with regular kitchen wastes. Unfortunately, there is no provision of waste segregation at any dumping points, and around 17,000 tons per year of soft plastics are going to the landfill with regular kitchen wastes. This volume escalates with the increasing population in the city. These openly dumped plastics either make a layer of plastic in the sub-surface or get washed to the rivers and seas. Therefore, non-degradable plastic waste accounts for $73 \%$ of litter in any aquatic habitat, with roughly $50 \%$ of them disposed of after a single use. We must have noticed many images and reports on how marine lives and biodiversity are devastated by eating small plastics flakes-those tiny pieces of plastic move through the food chain.

As the landfill sites in Bangladesh start receiving more and more plastics every year, the future risk of groundwater pollution becomes eminent. As the population rises and industries continue to grow, Bangladesh's dependence on groundwater increases proportionally. In 1970, the introduction of shallow tube wells increased resilience among Bangladeshi people, infants, and newborns, by protecting them against waterborne diseases. Before introducing shallow tube wells, water from wells, homestead water tanks, ponds, and rivers were the main sources for drinking water and other domestic purposes for the people, which increased their vulnerability to waterborne diseases. Some solutions to tackle this issue were boiling and filtering surface water, harvesting rainwater, use of water purification tablets, and drinking deep tube well water. International donors like UNICEF popular in villages patronized shallow wells and local politicians popularized their use, capitalizing on this opportunity, using it as a means of engaging locals and 
distributing them to their potential vote banks. Over time, this had an impact on societal behavior, associating having a tube well in the home yard as a symbol of family identity and stature. This shows how human interactions, decisions, values, interests, and relationships are embedded in knowledge production. Thus, despite being relatively the most expensive solution, shallow tube wells became a presiding feature in rural regions of Bangladesh. And in the urban regions, deep tube wells became the major source of piped water for everyday use. Dhaka Water Supply and Sewerage Authority (D-WASA), an independent organization established in 1963 serves around 12.5 million people with 2110 million liters of water each day mainly extracted from groundwater resources. And since the 1980s, water tables have been decreasing under the influence of deep extraction for the city's municipal supply $[32,33]$.

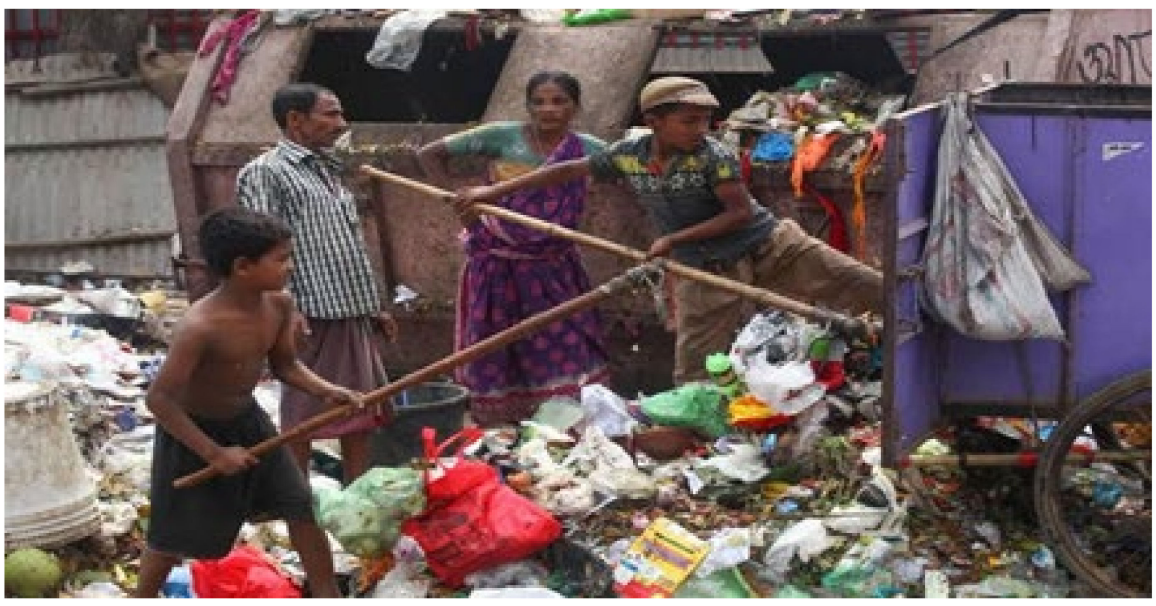

Figure 2. Plastic traveling from domestic disposal to a local dumping station (Photo: Authors).

\subsection{Plastic Governance in Bangladesh}

Global environmentalists are more concerned and united in pushing environmental protection actions against plastic. In December 2017, about 200 nations at the UN Environment Assembly held in Nairobi signed a resolution to immediately obliterate plastic pollution in oceans. Soon after, a plastic strategy calling was released by the European Commission for reduced consumption of single-use plastic and all plastic packaging in the EU market to be reusable or recyclable by 2030. In March 2019, one hundred and seventy countries echoed the EU's covenant to "significantly reduce" throwaway plastics by 2030. Many nations, particularly the rich countries, have invested their strategies and resources in plastic waste management, i. e., recycling. Plastic waste management is being viewed as both an issue of elimination and management. But the scenario is different for Bangladesh. The country recognized the problem two decades ago and responded by banning polymer shopping bags. Ironically, Bangladesh is at present one of the largest users of plastic in the world. National plastics industries produce essential products for readymade garments, construction, packaging, and household. Only 5\% of Bangladesh's total plastic waste reaches landfills. As mentioned earlier, three-fourth of litter in aquatic habitats are nondegradable plastic, and about half of them are single-use. This situation might deteriorate with the increasing population in the city and the changing economy. Figure 1 portrays one of the recurrent examples of how plastics are outspread in a city slum area. Plastics are either thrown away negligently anywhere or reaches the city corporation dumping stations from domestic and public garbage bins but eventually end up degrading away in landfill sites. Proper political drive to integrate the 2019 Nairobi plastic pollution declaration seems to be missing. Thus, laws, legislation, and policy guidelines on sustainable plastic use and management are lacking. 


\subsubsection{Policy Landscape in Bangladesh}

Bangladesh has come a long way since the 1990s in formulating policies to bring environmental pollution under control. Several relevant acts, regulations such as the Factory Act (1965), Environmental Pollution Control Ordinance (1977), Dhaka Municipal Ordinance (1983), Urban Management Policy Statement (1998), National Agricultural Policy (1999), Environmental Conservation Act (2002), National Environment Management Action Plan (NEMAP 1995-2005), Renewable Energy Policy (2008), the Local Government (City Corporation) Act 2009 (Amendment-2011), National 3R Strategy (2010) has been formulated to limit the consequences of technological advancement on the environment. These policies talk about the basics of citizen rights, roles and responsibilities of the city corporations, and environmental protection, and so on. Again, though the city corporation has stakes on policies around environmental protection, they are mainly looked after by the Department of Environment (DoE) and other government departments who often do not work in close coordination with the city corporation. For example, a senior officer of the DNCC informed that in 2011 the DOE distributed a huge number of color-coded bins to some pilot areas in the city, without even discussing with the city authorities. The project ended with no output. Moreover, none of these policies has prioritized plastic as a part of the environmental problem in Bangladesh. Even the most recent waste report of Dhaka North City Corporation does not have a single mention of plastic, neither it has recognized plastic as a waste [34].

Regarding the rising plastic waste, Bangladesh was one of the first countries in the world to implement a nationwide ban on plastic shopping bags, given the tendency of submerged plastic bags to exacerbate floods [35]. However, the ban was not genuinely successful given countrywide lenient enforcement. Adding to the collapse was the lack of available cost-effective alternatives. Environmental policy interventions themselves create newer constraints and incentives that can affect technological progress [36]. However, many policies such as National Agricultural Policy (1999), Urban Management Policy Statement (1998) focus on specific aspects of waste. Still, they do not outline particular attributes such as waste recovery or management [37]. Acts such as the Environmental Court Act 2000 only feature environmental pollution with no reference to waste management.

Currently, the plastic sector, directly and indirectly, employs 1.2 million people in Bangladesh [30]. Many people are involved in the process, beginning with raw material processing, supply, manufacture, and distribution to reach the consumer's hand. $8 \%$ of the total waste generated within Bangladesh is composed of plastics, among which 0.79 MMT plastics are openly dumped in the land every year without further processing and $0.12-0.31$ MMT per year finds their way to the ocean [7,38]. Degradation of the different types of plastics such as polyethylene terephthalate, HDPE, polyvinyl chloride, low-density polyethylene, polypropylene, polystyrene to macro, meso, micro, and nanoparticles occurs over time. Once released to the environment, treatment of bi-products such as PFOS and PFOA become even more challenging, as many conventional technologies that are used to treat organic contaminants in groundwater have proven to be ineffective or inefficient [39]. Moreover, Dhaka has a finite and declining groundwater resource [40] supplying water for domestic, industrial, and commercial use to millions of people. No existing policies focus on groundwater pollution. Most policies, including the groundwater management ordinance (1985), speak of infrastructural groundwater management at sub-district levels, which is a challenge in the absence of proper institutional arrangements [41].

Present waste management scenarios and policies pose a severe threat to public health and safety. The high cost of recycling, lenient waste management [42] lack of technologies and awareness are the steering forces of dumping of waste plastics in the land and both small and large water bodies such as channels, lakes, rivers, and even to the sea [43] which consequently contributes to the infertility of soil and contamination of water to an extent beyond conventional management mechanisms. Policies do not consider the gravity of plastic pollution in groundwater resources in Dhaka and lack proper implementation 
strategies. Integrated policy approaches should be taken with consistent measures to raise awareness, recycle, and dispose to mitigate plastic pollution.

\subsubsection{Institutions and Agencies}

As appears in the policies and DNCC's official documents, waste management is the most important responsibility of the city corporation. In the earlier section, we mentioned waste collectors while describing the flow of sing-use plastic from its domestic end-user to a landfill. They are recruited by the community-based organizations (CBOs) that manage the transfer of household wastes to a city corporation-designated secondary transfer station. The city corporation recognises these CBOs since 1987 as the Primary Waste Collection Service Provider (PWCSP). These PWCSPs function differently in different neighborhoods. In a middle-class neighborhood, every household contributes a regular payment to local volunteers to manage this activity. In an upper-class area, this task is rather given to a private contractor who happens to be a local muscleman. We have shared a case of a poor neighborhood in Figure 1. In recent years, officially city corporations are trying to privatize this service. Though, a senior member of DNCC told us that there are more and more cases of local gangsters taking the PWCSP role. We have also cross-checked this with the waste collectors and old members of local volunteers. In summary, though plastic has not been prioritized as a subject of environmental damage and future risk by legitimate waste management institutions, however, the function of waste management is gradually going under the control of a group that has far less accountability to society.

\subsection{Remediation Strategies}

Prevention is better than cure. Reduction of plastic use, starting from public awareness and legislation to remove plastic microbeads from self-care products, notable attempts at source reduction, reuse, and landfilling have been employed to reduce the necessary amount of plastic waste generated worldwide. However, only $9 \%$ of the plastics are recycled because we lack the technology to turn dirty waste plastics into virgin quality materials. At present, the only widely employed method in recycling plastics is mechanical. The organic component is recovered by cleaning and is then shredded, melted, and remoldedfrequently in a mixture with virgin plastic of the same type, this mixture is then used to manufacture new plastic goods [44]. However, this approach cannot be applied to composites and thermosets. PET and various types of PE are recovered by processing mechanically, accounting for $9 \%$ and $37 \%$ of all plastics manufactured, while only around $1 \%$ of the residue is recovered [44].

The scenario is changing slowly, and some companies are working towards using short-chain polymer compounds. There is enormous scope for using such compounds in the construction sector. In Bangladesh particularly, adding small amounts of adequately selected polymers to cement-based structural materials used conventionally could protect infrastructures in flood-prone areas, saving huge revenue every year [45].

Alternatives of plastics are being introduced, being called bioplastics derived entirely from sustainable sources of biomass such as vegetable fats and oils, corn starch, cellulose, and lactic acid [46]. They can be made from a combination of agricultural waste and disposed-of plastic bottles and other containers, allowing freedom to tweak their properties. Another plastic management process, incineration, is a debated yet viable technology for plastic waste management. In Singapore, given the limited land resources, solid waste incineration is given precedence over all other waste transformation options [47]. They now successfully follow the waste-to-energy protocol minimizing the mass of waste dumped into landfills. Pyrolysis can also be an alternative method and is growing in Bangladesh. It produces less toxic substances under appropriate conditions with variable amounts of potentially valuable by-products [48]. Next, a number of studies evaluated the capacity of regular and innovational WWTP technologies to remove plastics $[49,50]$ through advanced wastewater technologies such as membranes, electrodeposition, and coagulation [51]. Other inventive tertiary treatment methods such as rapid gravity sand 
filters and dissolved air flotation, provide removal rates of microplastics $>95 \%$ from primary and secondary effluents [51]. There are also other innovative technologies targeting the removal of different polymers.

Although research investigating the harmful toxicological effects of chemicals associated with plastics is limited, the threat is real and is here now. Most remediation strategies are viable but expensive. The feasibility of scaling in a developing country like Bangladesh is questionable. Proper development of the policy for chemical exposure caused by plastic must be urgently implemented with encouraging research in the Global South. Developing more innovative and recyclable plastic materials and efficient recycling and wastewater treatment processes must be investigated thoroughly. The mass population of Dhaka city needs to be made aware of the mechanisms and severity of the problem and the hazards of plastics on human health.

\section{Conclusions}

Plastics are essential materials in the 21st century, practically found everywhere, powerfully influencing our daily lives in many different ways. The mass of plastics produced in the first ten years of this century is likely to approach the amount built in the entire century that preceded. Hence, it is urgent to accelerate research and understanding of how plastics can impact human health. And one such most under-researched route is groundwater contamination. The recent surge in research on this contaminant threat broadly focuses on surface waters (mainly oceans and rivers), while aquifer contamination is only marginally mentioned, and mostly as an issue needing further investigation. Emerging issues, such as climate change, etc., will worsen the situation, increasing photo degradability and toxication rate through waterlogging and accelerating groundwater infiltration. This research area also remains unexplored. In addition, there is a vast grey area on understanding the dimensions of responsibility and accountability, and more generally, governance of plastic waste management and its effects on the matter. There are several scattered initiatives without any concrete indication at the national level. Therefore, a precise understanding and awareness at different levels are crucial.

This paper offers an opportunity to discuss the plastic and groundwater nexus in the context of the Global South. This also engages with Beck's 'risk society' to make this relevant to the global South, used only in the North. Hopefully, this paper will contribute to a new vision in collective activities towards the informed and responsible use of plastics.

Though Dhaka is taken as a case, this could be relevant to many cities across the globe that are not managing single-use plastic only because this is economically not viable. We explained earlier how depleting single-use plastic and its chemicals could affect our body through drinking water intake, devastating long-term health consequences for the future generation. Already there is an abundance of plastic we dumped into nature and will not be able to remove. Therefore, we like it or not, and we will never be able to return to normal. However, for the sake of better earth in the years to come, we can certainly (a) make a call for zero plastic pollution; (b) extract as much plastic as we could from nature; (c) invest in new technologies to clean plastic from the nature, and (d) prepare ourselves to face the health consequences in future from plastic contamination.

Author Contributions: Conceptualization, M.N.; methodology, M.N. and H.J.S.; data collection, M.N., A.A.E. and H.J.S.; validation, M.N., A.A.E. and H.J.S.; formal analysis, M.N. and H.J.S.; resources, M.N., A.A.E. and H.J.S.; data curation, M.N., H.J.S. and A.A.E.; writing-original draft preparation, M.N.; writing-review and editing, M.N., H.J.S. and A.A.E.; visualization, M.N. and H.J.S.; supervision, M.N.; project administration, M.N. All authors have read and agreed to the published version of the manuscript.

Funding: All the authors contributed from their paid full-time job. There was no direct funding for conducting the fieldwork and other associated works.

Data Availability Statement: Not applicable. 


\begin{abstract}
Acknowledgments: We would like to thank all the experts and practitioners who have supported writing up the research by providing their reflections and comments on different aspects of the total write-up. We are also highly indebted to the reviewers for reading the paper and helping to strengthen the quality of the article by giving their comments. MN's authorship is funded by the Deutsche Forschungsgemeinschaft (DFG, German Research Foundation) under Germany's Excellence Strategy-EXC 2037 'CLICCS-Climate, Climatic Change, and Society'_Project Number: 390683824, contribution to the Center for Earth System Research and Sustainability (CEN) of Universität Hamburg.
\end{abstract}

Conflicts of Interest: The authors declare no conflict of interest.

\title{
References
}

1. Hosler, D.; Burkett, S.; Tarkanian, M. Prehistoric polymers: Rubber processing in ancient mesoamerica. Science 1999, 284, 1988-1991. [CrossRef] [PubMed]

2. Davis, H. Life and death in the anthropocene. In The Routledge Companion to Critical Approaches to Contemporary Architecture; Chattopadhyay, S., White, J., Eds.; Routledge: New York, NY, USA, 2019; pp. 80-90.

3. Islam, M.S. Prospects and challenges of plastic industries in Bangladesh. J. Chem. Eng. 2012, 26, 16-21. [CrossRef]

4. Hopewell, J.; Dvorak, R.; Kosior, E. Plastics recycling: Challenges and opportunities. Philos. Trans. R. Soc. B Biol. Sci. 2009, 364, 2115-2126. [CrossRef] [PubMed]

5. Kosuth, M.; Mason, S.A.; Wattenberg, E.V. Anthropogenic contamination of tap water, beer, and sea salt. PLoS ONE 2018, 13, e0194970. [CrossRef]

6. Van Rensburg, M.; Nkomo, S.; Dube, T. The 'plastic waste era': Social perceptions towards single-use plastic consumption and impacts on the marine environment in Durban, South Africa. Appl. Geogr. 2020, 114, 102-132. [CrossRef]

7. Jambeck, J.R.; Geyer, R.; Wilcox, C.; Siegler, T.R.; Perryman, M.; Andrady, A.; Narayan, R.; Law, K.L. Plastic waste inputs from land into the ocean. Science 2015, 347, 768-771. [CrossRef]

8. Lim, X.Z. Microplastics are everywhere-But are they harmful? Nature 2021, 593, 22-25. [CrossRef]

9. Buchanan, J. Pollution by synthetic fibres. Mar. Pollut. Bull. 1971, 2, 23. [CrossRef]

10. Carpenter, E.J.; Smith, K., Jr. Plastics on the Sargasso sea surface. Science 1972, 175, 1240-1241. [CrossRef]

11. Beck, U. Risk Society: Toward a New Modernity; SAGE Publications Ltd.: Thousand Oaks, CA, USA, 1992.

12. Cohen, M.J. Risk society and ecological modernisation alternative visions for post-industrial nations. Futures 1997, 29, 105-119. [CrossRef]

13. Korstanje, M.E. Book Review of Kai Erikson's (1994) A new species of trouble: Explorations in disaster, trauma and community. Eur. J. Psychol. 2010, 6, 175-179. [CrossRef]

14. Campanale, C.; Massarelli, C.; Savino, I.; Locaputo, V.; Uricchio, V.F. A detailed review study on potential effects of microplastics and additives of concern on human health. Int. J. Environ. Res. Public Health 2020, 17, 1212. [CrossRef] [PubMed]

15. Andrady, A.L. Microplastics in the marine environment. Mar. Pollut. Bull. 2011, 62, 1596-1605. [CrossRef] [PubMed]

16. Hahladakis, J.N.; Velis, C.A.; Weber, R.; Iacovidou, E.; Purnell, P. An overview of chemical additives present in plastics: Migration, release, fate and environmental impact during their use, disposal and recycling. J. Hazard. Mater. 2018, 344, 179-199. [CrossRef]

17. Schirinzi, G.; Pérez-Pomeda, I.; Sanchís, J.; Rossini, C.; Farré, M.; Barceló, D. Cytotoxic effects of commonly used nanomaterials and microplastics on cerebral and epithelial human cells. Environ. Res. 2017, 159, 579-587. [CrossRef]

18. Til, H.; Feron, V.; Immel, H. Lifetime (149 weeks) oral carcinogenicity study of vinyl chloride in rats. Food Chem. Toxicol. 1991, 29, 713-718. [CrossRef]

19. Mahler, G.; Esch, M.T.; Southard, T.; Archer, S.; Glahn, R.; Shuler, M. Oral exposure to polystyrene nanoparticles affects iron absorption. Nat. Nanotechnol. 2012, 7, 264-271. [CrossRef]

20. Inkielewicz-Stepniak, I.; Tajber, L.; Behan, G.; Zhang, H.; Radomski, M.; Medina, C.; Santos-Martinez, M. The role of mucin in the toxicological impact of polystyrene nanoparticles. Materials 2018, 11, 724. [CrossRef]

21. Lehner, R.; Weder, C.; Petri-Fink, A.; Rothen-Rutishauser, B. Emergence of nanoplastic in the environment and possible impact on human health. Environ. Sci. Technol. 2019, 53, 1748-1765. [CrossRef]

22. Hansen, E.; Nilsson, N.H.; Lithner, D.; Lassen, C. Hazardous Substances in Plastic Materials; COWI in Cooperation with Danish Technological Institute on behalf of The Norwegian Climate and Pollution Agency: Vejle, Denmark, 2013; Available online: https:/ / www.byggemiljo.no/wp-content/uploads/2014/10/72_ta3017.pdf (accessed on 23 February 2021).

23. Hwang, J.; Choi, D.; Han, S.; Choi, J.; Hong, J. An assessment of the toxicity of polypropylene microplastics in human derived cells. Sci. Total Environ. 2019, 684, 657-669. [CrossRef]

24. Meeker, J.; Sathyanarayana, S.; Swan, S. Phthalates and other additives in plastics: Human exposure and associated health outcomes. Philos. Trans. R. Soc. Lond. Ser. B Biol. Sci. 2009, 364, 2097-2113. [CrossRef]

25. Bornehag, C.; Sundell, J.; Weschler, C.; Sigsgaard, T.; Lundgren, B.; Hasselgren, M.; Hagerhed-Engman, L. The association between asthma and allergic symptoms in children and phthalates in house dust: A nested case-control study. Environ. Health Perspect. 2004, 112, 1393-1397. [CrossRef] 
26. Panno, S.V.; Kelly, W.R.; Scott, J.; Zheng, W.; McNeish, R.E.; Holm, N.; Hoellein, T.J.; Baranski, E.L. Microplastic Contamination in karst groundwater systems. Groundwater 2019, 57, 189-196. [CrossRef]

27. Kim, H.; Lee, J.-Y. Emerging concerns about microplastic pollution on groundwater in South Korea. Sustainability 2020, 12, 5275. [CrossRef]

28. Tembon, M. Tackling Plastic Pollution for Green Growth in Bangladesh. World Bank Blogs 2021. Available online: https://blogs. worldbank.org/endpovertyinsouthasia/tackling-plastic-pollution-green-growth-bangladesh (accessed on 13 September 2021).

29. Yang, H.; Ma, M.; Thompson, J.R.; Flower, R.J. Waste management, informal recycling, environmental pollution and public health. J. Epidemiol. Community Health 2018, 72, 237-243. [CrossRef]

30. USAID. Bangladesh Comprehensive Private Sector Assessment; United States Agency for International Development (USAID): Dhaka, Bangladesh, 2019. Available online: https:/ / pdf.usaid.gov/pdf_docs/PA00TWMH.pdf (accessed on 5 September 2020).

31. BIGD. The State of Cities: Solid Waste Management of Dhaka City-Towards Decentralised; Retrieved from BRAC Institute of Governance and Development; BRAC Institute of Governance and Development, BRAC University: Dhaka, Bangladesh, 2015.

32. Knappett, P.; Mailloux, B.; Choudhury, I.; Khan, M.; Michael, H.; Barua, S.; van Geen, A. Vulnerability of low-arsenic aquifers to municipal pumping in Bangladesh. J. Hydrol. 2016, 539, 674-686. [CrossRef]

33. Mozumder, M.; Michael, H.; Mihajlov, I.; Khan, M.; Knappett, P.; Bostick, B.; Mailloux, B.J.; Ahmed, K.M.; Choudhury, I.; Koffman, T.; et al. Origin of groundwater arsenic in a rural pleistocene aquifer in Bangladesh depressurized by distal municipal pumping. Water Resour. Res. 2020, 56, e2020WR027178. [CrossRef]

34. DNCC. Waste Report 2018-19; Dhaka North City Corporation: Dhaka, Bangladesh, 2019. Available online: https: //dncc.gov.bd/sites/default/files/files/dncc.portal.gov.bd/annual_reports/6693c776_0dde_49da_b85b_1928d398a7f4/2 020-07-07-15-04-0388efe51e61d331efb81045a0648dd2.pdf (accessed on 15 September 2021).

35. Xanthos, D.; Walker, T. International policies to reduce plastic marine pollution from single-use plastics (plastic bags and microbeads): A review. Mar. Pollut. Bull. 2017, 118, 17-26. [CrossRef]

36. Jaffe, A.B.; Newell, R.G.; Stavins, R.N. Environmental policy and technological change. Environ. Resour. Econ. 2002, 22, 41-70. [CrossRef]

37. Shams, S.; Sahu, J.; Rahman, S.; Ahsan, A. Sustainable waste management policy in Bangladesh for reduction of greenhouse gases. Sustain. Cities Soc. 2017, 33, 18-26. [CrossRef]

38. Lebreton, L.; van der Zwet, J.; Damsteeg, J.-W.; Slat, B.; Andrady, A.; Reisser, J. River plastic emissions to the world's oceans. Nat. Commun. 2017, 8, 15611. [CrossRef]

39. Schaefer, C.E.; Andaya, C.; Urtiaga, A.; McKenzie, E.R.; Higgins, C.P. Electrochemical treatment of perfluorooctanoic acid (PFOA) and perfluorooctane sulfonic acid (PFOS) in groundwater impacted by aqueous film forming foams (AFFFs). J. Hazard. Mater. 2015, 295, 170-175. [CrossRef]

40. Hoque, M.; Hoque, M.; Ahmed, K. Declining groundwater level and aquifer dewatering in Dhaka metropolitan area, Bangladesh: Causes and quantification. Hydrogeol. J. 2007, 15, 1523-1534. [CrossRef]

41. Qureshi, A.; Ahmed, Z.; Krupnik, T. Groundwater Management in Bangladesh: An Analysis of Problems and Opportunities; Cereal Systems Initiative for South Asia Mechanization and Irrigation (CSISA-MI) Project; International Maize and Wheat Improvement Center (CIMMYT): Dhaka, Bangladesh, 2014; Available online: http:/ / hdl.handle.net/10883/4273 (accessed on 2 October 2020).

42. Zia, H.; Devadas, V.; Shukla, S. Assessing informal waste recycling in Kanpur City, India. Manag. Environ. Qual. Int. J. 2008, 19, 597-612. [CrossRef]

43. Castaldi, M.J. Perspectives on sustainable waste management. Annu. Rev. Chem. Biomol. Eng. 2014, 5, 547-562. [CrossRef] [PubMed]

44. Rhodes, C.J. Plastic pollution and potential solutions. Sci. Prog. 2018, 101, 207-260. [CrossRef] [PubMed]

45. Islam, M.; Rahman, M.; Ahmed, M. Polymer-modified concrete: World experience and potential to Bangladesh. Indian Concr. J. 2011, 22, 55-63.

46. Wierckx, N.; Narancic, T.; Eberlein, C.; Wei, R.; Drzyzga, O.; Magnin, A.; Ballerstedt, H.; Kenny, S.T.; Pollet, E.; Avérous, L.; et al. Plastic biodegradation: Challenges and opportunities. In Consequences of Microbial Interactions with Hydrocarbons, Oils, and Lipids: Biodegradation and Bioremediation. Handbook of Hydrocarbon and Lipid Microbiology; Steffan, R., Ed.; Springer: Cham, Switzerland, 2018; pp. 1-29. [CrossRef]

47. Bai, R.; Sutanto, M. The practice and challenges of solid waste management in Singapore. Waste Manag. 2002, 22, 557-567. [CrossRef]

48. Verma, R.; Vinoda, K.; Papireddy, M.; Gowda, A. Toxic pollutants from plastic waste-A review. Procedia Environ. Sci. 2016, 35 701-708. [CrossRef]

49. Talvitie, J.; Mikola, A.; Koistinen, A.; Setälä, O. Solutions to microplastic pollution-Removal of microplastics from wastewater effluent with advanced wastewater treatment technologies. Water Res. 2017, 123, 401-407. [CrossRef]

50. Lares, M.; Ncibi, M.C.; Sillanpää, M.; Sillanpää, M. Occurrence, identification and removal of microplastic particles and fibers in conventional activated sludge process and advanced MBR technology. Water Res. 2018, 133, 236-246. [CrossRef]

51. Picó, Y.; Barceló, D. Analysis and prevention of microplastics pollution in water: Current perspectives and future directions. ACS Omega 2019, 4, 6709-6719. [CrossRef] 